\title{
Comparison of factors influencing the Internationalisation Process in France and Poland
}

\begin{abstract}
The aim of this article is to reveal crucial factors (political, administrative and financial) that influence the attitudes of local governments in the internationalisation process. The paper's conclusions are based on a study referring to various types of analyses, both quantitative and qualitative, of official documents, databases as well as in-depth interviews. The study was conducted in Lublin, Poland and Nancy in France.

The research shows that the local governments' attitudes towards international cooperation depend greatly on political factors. In both cases (Lublin and Nancy), despite the differences in political and administrative systems; the nature, activity and range of the existing cooperation is governed much more by the mayor's ability, his/her individual attitude and approach than by the city's councillors.

Keywords

Internationalization $\bullet$ local government $\cdot$ Nancy $\cdot$ Lublin $\bullet$ France $\bullet$ Poland (c) University of Warsaw - Faculty of Geography and Regional Studies
\end{abstract}

\author{
Agnieszka Laskowska \\ Department of Local Development and Policy \\ Faculty of Geography and Regional Studies \\ University of Warsaw, Poland \\ e-mail: agnieszkalaskowska@hotmail.com \\ Received: 04 April 2016 \\ Accepted: 06 May 2016
}

\section{Introduction}

The phenomenon of international (cross-border) cooperation is common in European local governments. The running of international activities by local governments is made possible through a process of decentralization. The delegation of certain tasks and obligations by the state to local government has increased the autonomy of local governments when conducting international activities and has given them a strong position in international discourse. The main goal of the article is to determine what factors have decisive roles and so influence the attitudes (the way of behaving) of cities in cross-border cooperation in Poland and France. This paper focuses principally on political and administrative factors. The political factor concerns the abilities (their scope determined by local law) and activities (designated by personal characteristics) of political leaders and administrative officials. Detailed research was carried out in the Polish city of Lublin and its French twined-city, Nancy. The chosen cities are active in the international arena, but they manage cross-border cooperation in different ways.

The idea of establishing direct and permanent contact between municipalities was created after the end of the World War II. It had to break the barriers and reduce the damage that had grown between nations as a result of hostile attitudes and actions (Hałas \& Porawski 2003). Currently there are territorial units within every European country cooperating with foreign entities. In 2003, just between fifteen 'old' EU countries, there were over 7,000 formal partnerships (Hałas \& Porawski 2003). In Poland, the number of twined municipalities began to steadily increase after 1990 (Brzozowska 1998). By 2012 the partnership agreement had been signed by approximately $95 \%$ of urban and $52 \%$ of rural communities (Fuksiewicz et al. 2012). In the case of Poland, relations between local government units are diverse, ranging from spontaneous projects, to strictly organized cooperation (Szewczyk 2007). In France, since 1997, a decrease in the number of new relationships between municipalities' has been observed. Up until 2013, every big French city had signed partnership agreements with foreign communities. Moreover, in the case of French cities, the development of more enhanced and sophisticated forms of cooperation and a decline in using traditional ones (popular in smaller communities) was observed (Allies et al. 2003).

Cross-border cooperation, local leadership and learning organization

For the purposes of this article, cross-border cooperation and international cooperation are used interchangeably. Both terms should be understood as meaning mutual and interconnected relations, based on cooperation that is a joint action, and which brings benefits to the stakeholders (Szmigiel-Rawska 2008). In general these relations work on a foundation of written legal agreements between the territorial units in different countries. They are often defined interchangeably as foreign partnerships, and also as twined cities/relations. According to some points of view twined relations are understood to be international contacts between the local authorities of various countries, characterized by the direct involvement of residents of a territorial unit and local organizations in cooperation with foreign communities (see Szewczyk 2007). The increased interest in cross-border cooperation by local governments is associated with the rapid progress of globalization. New relationships in power and competition have occurred; the number of international actors has increased and the importance of paradiplomacy has escalated. State and local governments are one of many actors on the international scene (Cieśla 2000; Giddens 1990). The concept of 'municipal 
internationalism' by N. Clarke (2010) arose from this trend. The author points out that the functioning of local governments on a growing scale depends on decisions taken abroad.

The degree of involvement of each local government in crossborder cooperation depends on the scale of entrepreneurship of local authorities and the individual features of their leaders. Theories about political entrepreneurship show a high degree of efficiency in using this method to accomplish the goals of local politics. At the same time, they pay attention to attributes that should characterize enterprising politicians. Theories on political entrepreneurship outline that the personality of the political entrepreneur, who has some distinguishing features, allows us to identify him as the local leader (Mintron \& Norman 2009). According to network theories, a leader is an entity that gives impetus to joint actions and involvement of local government, and determines the exchange of information (Szmigiel-Rawska, Dziemianowicz \& Szlachta 2010). However, according to Hermann (1998), the leadership process is never the same. Determining the factors for a leader's behaviour never gives the same results. Both the multitude of factors influencing the leader's role (such as setting goals and meeting the needs of groups (Tucker 1981)), and the approaches to the analysis of this issue, have led to the development of a number of theories relating to leadership that emphasize its crucial importance. The leader is responsible for the 'world decisions of the community'. 'House's Paths Goal Theory' assumes that the leader indicates courses of action and supports subordinates in achieving the objectives set by him (Stoner, Freeman \& Gilbert Jr. 2001).

Apart from the figure of the leader, 'the administrative background' is also important for the functioning of local government. Authorities should seek to permanently strengthen their abilities in order to shape their future through the increased involvement of employees. According to the 'learning organization' theory, employees are the engine and originators of change occurring within the organization. The learning organization is characterized by teamwork that strengthens synergies' effects. Senge's concept assumes that if the team is able to learn, the organization will also learn (Kocot 2006). Dissemination of knowledge within the office is one of the determinants of the 'learning organization'. In the social sciences internalization is understood as 'a process of taking over from the environment in an organized or spontaneous way, certain patterns of conduct or values in force within the community' (Konstańczak 2001) and consider them as their own (Leksykon PWN 1972). Thus, the internalization of knowledge within administrative structures will apply to the distribution of information between the various departments of the office, and the creation of new solutions based on available knowledge.

\section{Research method}

In this research; data for the legislation, reports and documents on international cooperation of local governments in Poland and France, from 1989 to 2014, which related to Nancy and Lublin's international cooperation; were analysed. To achieve a more complete picture of these cities' cross-border cooperation, analysis of the literature and available electronic data was supplemented by the examination of available documents from the archives of the city of Nancy. Moreover, interviews with representatives (the mayor, a councillor, and officials) of Nancy and Lublin were undertaken in 2014.

A comparison of legislative conditions for enabling crossborder cooperation

The degree of power decentralization in a country has a significant impact on the attitudes of local governments actions (see Kersting \& Vetter 2003; Wollmann \& Bouckaert 2006). The law regulating the scope of local government's independence directly affects the local government.

The differences and similarities between the municipal governments in Poland and France, under national legislation, affect the overall scope of the freedom of action of the local government ${ }^{1}$. Thus, these impact cross-border cooperation in the same way as they impact local business communities. The strong position of the executive body in both local governments, ensures that the leader has a dominant opinion in framing the vision and directions of local government activities. The differences in the parties' degree of activity in Polish and French local governments, and the selection method used for selecting local authorities, determines the kind of relations, or lack of them, between the executive body and legislative body within the community. For example, implementation of the executive body's ideas is easier when it has a majority in the municipal council, which is a common phenomenon in French local government due to the mayoral election process. Moreover, a Polish municipal council has the right to control and influence the mayor's activities. Meanwhile, French city councils do not have the same rights. The size of municipal entities is associated with their function of authority (ceremonial functions vs. responsibilities for providing public services), their range of responsibilities and ways of management. The small size of French communes limits their activities on the international scene but the experience generated from different forms of local cooperation could also be transferred easily to the international ground.

The impact on municipalities' independence, of the remit granted in international relations

The international activities, in addition to system solutions, are also shaped by international and national legislation relating to cross-border cooperation. International legal acts have a general nature and create a framework for this type of cooperation, while national legislation lays down in detail the rights and obligations relating to the international cooperation of municipalities. There are basic differences in the degree of autonomy of local governments when conducting international activities in Poland and France ${ }^{2}$

French legislation, unlike Polish legislation, defines the cooperation's purpose and its conditions, which have to be met in order for the state to recognize the agreement concluded between the local entities. Moreover, there are several provisions within French legislation concerning specific regulations on local governments' international cooperation. For example, seven principles have been identified that international cooperation cannot concern (among these is: the principle of the indivisibility of the Republic and sovereignty of France). Most of the abilities the legislature gives to the French territorial unit, in the context of cross-border cooperation, are bound to the details. In both

${ }^{1}$ Description of the differences in Polish and French local government was based on the following acts: Constitution de la République française, Code Générale des Collectivités Territoriales (CGCT), circulaire INT/A/91 00108 C; Konstytucja RP z dn. 2 kwietnia 1997r. Dz. U. 1997 nr 78 poz. 483, Ustawa z dnia 8 maja 1990r. o samorządzie gminnym. For more details see: Laskowska, A 2014, Polityczne $i$ administracyjne czynniki wpływające na postawę samorządu gminnego w relacjach transgranicznych. Porównanie Nancy i Lublina, Master's thesis at the University of Warsaw.

${ }^{2}$ In Poland, legal acts governing the scope of international cooperation by local government shall be consistent with: Konstytucja RP z dn. 2 kwietnia 1997r. Dz. U. 1997 nr 78 poz. 483, Ustawa z dnia 15 września 2000 r. o zasadach przystępowania jednostek samorządu terytorialnego do międzynarodowych zrzeszeń społeczności lokalnych i regionalnych, Ustawa z dnia 8 maja 1990r. o samorządzie gminnym. In France, international cooperation is regulated by: Code Générale des Collectivités territoriales, la loi de Thiollière of 2007, La loi Oudin - Sautini of 7.12.2006, Circulaire NOR / INT / B / 01/00124 / C bis of 20.04.2001 and circulaire NOR / INT / B / 01/00124 / $\mathrm{C}$ of 04.21.2001. For more details see: Laskowska, A 2014, Polityczne i administracyjne czynniki wpływające na postawę samorządu gminnego w relacjach transgranicznych. Porównanie Nancy i Lublina, Master's thesis at the University of Warsaw. 
countries, Poland and France, municipalities have to act within the limits of their power, remit and duties (under the general clause). Meanwhile, Poland's law on local government outlines that cooperation with foreign local communities is the community's 'own task'. In the countries analysed, the way of joining twined agreements is different. In Poland, the procedure is longer and involves, beyond the municipal council, the governor of the region (central government representative) and the Minister of Foreign Affairs. In France, the cooperation agreement comes into force when it is delivered to the state representative in the department who checks its legality. Moreover, France established the National Commission for Decentralised Cooperation and the 'Delegation for the External Action of Territorial Communities' within the Ministry of Foreign and European Affairs. These institutions help French local governments in conducting international cooperation. Polish legislation does not provide for the establishment of any institutions tasked with organizing and supervising the courses and activities of local governments' international cooperation.

\section{Case studies: Lublin and Nancy}

The study was conducted in Lublin, Poland and Nancy in France. The partnership agreement between the two cities was signed in 1988. Lublin, located in eastern Poland, is the capital of the Lubelskie Region and is an important academic centre in the region and in the country as a whole. It has established relations with more than thirty-two foreign cities from twentytwo countries. The first partnership was established by Lublin in 1988. Over the last few years Lublin has implemented at least one project with each of its partners. The largest group of Lublin's twin cities are in Ukraine. Polish cities' cooperation takes place mostly in the fields of culture and education, but also, depending on partner ability, in fields related to the functioning of local government, sports and the economy. In cooperation with eastern cities, Lublin also implemented many projects relating to the INTERREG and PHARE programs. The most common form of contact in Lublin's cross-border cooperation are working visits within the framework of joint projects, the visits by delegations from the city offices', exchange of experience etc. Nancy is a city located in eastern France. It is the second largest city in the region of Lorraine and is the capital of the department of Meurteet-Moselle. Nancy is an important regional academic centre and has signed twin agreements with eight cities from eight countries. Nancy established its first partnership in the 50 s but the last contract was signed in 1991. There are no cities from Eastern Europe among its partners. Nancy is cooperating in a wide range of areas: education, culture, environmental protection, medicine, new technologies and the fight against organized crime. The most common actions undertaken on an international scale are: exchange of delegations from city offices, participation in economic events, conferences organized by partners, and exchange of experts and experience.

Factors influencing the attitudes of Nancy and Lublin in cross-border cooperation

\section{The political factor}

The attitudes of local governments in cross-border cooperation are, to the greatest extent, dependant on political factors, and the executive authority has the biggest impact on these attitudes. In Lublin, the city's mayor directs international cooperation; he outlines the directions of international actions, has the final word on the determination of the shape of cooperation, and is informed about any international actions and their scale undertaken by the different departments of the city office. Nancy's international activities are the result of cooperation between the mayor, councillors and the administration. Each of the bodies mentioned above are involved but the mayor is the key player in the decision making process. His political will creates space for administrative officeholders and gives direction to its activities. He gives instructions to bureaucracy and has the final decision on pulling newcomers into international cooperation with the city. The mayor of a French city is ultimately responsible for international action, and every action within this domain requires his approval.

Nancy strives to make the best use of existing connections. The city develops and deepens cooperation within the framework of existing partnerships and does not acquire new partners (this being the mayor's decision). Lublin, by expanding cooperation with new cities, wants to strengthen its image and to show itself on the international stage. This is due to the general opinion of the mayor, which is that 'Lublin likes to get something to happen', and a willingness to distance itself from the prevailing stereotype that Lublin belongs to the less developed part of Poland. Geographical directions and areas of cooperation are also linked to the person holding executive functions. It is observed in changes to the areas of cooperation and Lublin's international initiatives. In the city, changes in international cooperation are linked to changes in the holder of the position of mayor of Lublin. The orientation of cross-border cooperation is usually determined by the personal interests of the mayors. Most often they intensify cooperation in the areas in which they 'feel confident. The current Lublin mayor emphasizes the development of partnerships with southeastern European countries. This is because of the outlined vision of the city's development, in the current term, as a strong centre in Eastern Europe. As a result of policies adopted by the current mayor of Lublin since 2010, international cooperation has adopted the character of a 'project to project' cooperation. It is also conducted in a more diverse way than during the terms of previous mayors. In Nancy, changes in international cooperation are often associated with changes to the mind set and priorities of the former mayor who held office for thirty-one years (until March 2014.). The mayor's attitude has evolved under the influences of various events such as participation in conferences. It is worth noting that only the directions of Nancy's cooperation were changed, but the overall policy concerning international cooperation has remained the same for last thirty-one years: that is favouring existing relations, without increasing the number of partnerships.

In both cities, the city council is the body with the least involvement in the international cooperation process. In Lublin, the council does not have any impact on international actions; its role is limited to the approval of resolutions concerning the launching of cooperation, which are usually accepted unanimously, and participation in foreign delegations or other events connected to the cross-border cooperation. It is worth noting that councillors' participation in the above-mentioned projects is not of their own initiative but constitutes a response to 'the city hall's invitation'. The limited influence of councillors on cooperation is proven, in Lublin, by the fact that there is no Committee for International Affairs. They are also, but very rarely, the initiators of Lublin's international projects. In Nancy's case, the council's influence on cooperation is visible, but it is the least significant when compared with the mayor's and the officials' engagement. All ideas concerning international actions are presented to the committee (consisting of councillors). It discusses the project's shape and revises it if required. Each part of the international cooperation has to be adopted in the form of a decision at the municipal level. The exceptions are projects ordered within the framework of projects commissioned by the ministry. 
The administrative factor

In Lublin and Nancy, the administrative factor is second in terms of importance after the political factor. Officials are the second group of actors that are engaged in international cooperation, just after the mayor. They are obligated to implement activities under criteria set by the leader (the mayor). Administrative factors are closely linked with tools used in international cooperation.

The office's organizational structure is especially conducive to internalizing knowledge and expertise of the city hall. In Nancy, the initiative of a specific level of implementation is managed by a specialized department. It is not the same as in Lublin where an initiative, from beginning to end, is coordinated by the International Relations Department, and only that department cooperates with other departments in the city office. In Nancy, when the scope of knowledge or competence of a given department is insufficient, another department specialised in the field acquires the project. In consequence, Nancy's foreign partners work, at various stages of the project, directly with a diverse range of departments. This structure allows them to achieve the best execution of the project and to help the International Cooperation Department. As a result, the entire city office is involved in the city's international cooperation and is able to perform a larger number of projects with foreign partners. The structure of the office in Nancy encourages the building of a learning organization, because it promotes the transmission of information and intensified cooperation between departments. In Lublin, we also deal with cooperation and information transfer, which leads to the acquisition of knowledge within the city hall. However, a structure in which one department is constantly involved during a project, hinders the functioning of the office and limits the scope of the spread of information.

The more advanced specialization of Nancy's actions refers to the method of selecting partners. Nancy, when choosing a foreign partner, is guided by its own potential as well as the partner's potential. According to city office representatives, the greater number of points in common translates into more areas for exchange and more effective cooperation. Economic and human resources within the partner city office are also important. Before Nancy decides to cooperate with a foreign city, it looks for information concerning the future partner (prepared analysis on its economic, social, cultural and demographic situation). In Lublin's case, the existing potential is important, but not the most important factor for cooperation. The Polish city also counts on the benefits that could be gained through cooperation and the possibility of implementing Lublin's vision and its selfinterest. Moreover, Lublin enters into relations with cities whose organizations have already been working with various Lublin organizations.

Nancy's authorities believe that cooperation has to be effective and active. The city is not afraid of breaking contracts with inactive partners. In 1996, Nancy broke the partnership agreement they had with the city of Piraeus in Greece, as they believed that this cooperation was becoming unproductive. Cooperation between the cities had been intense up until 1987, but the first considerations about breaking the agreement appeared on Nancy's side in 1993. The careful selection of twin cities is an outcome of the city authorities' political choice, in particular the mayor. In Nancy, the opinion is that: 'It is better to do what we started, to strengthen, to build trust and friendship with existing partners'. Nancy depends on carrying out in-depth cooperation, and this is impossible when you have many partners. However, this finding does not effect the establishment of cooperation with numerous foreign cities with which cooperation is not formalized. In most cases this is a one-time cooperation concerning individual projects. There is; however, a list of cities with which Nancy cooperated in an intense way during the same period of time, but with whom no agreement was signed. The French city also closely monitors their partners' situation. Numerous documents in the archives relating to cross-border cooperation reflect a detailed analysis of the situation of partner cities. For example, the cooperation with Newcastle was limited due to the financial difficulties of the British city in 1992.

In Lublin, despite the existence of several inactive twinned towns, there is a conviction that there are no appropriate tools for breaking agreements that were concluded for an indefinite period, and it would also be inappropriate. A representative of Lublin's city hall says that sometimes, after a period of 'dormant cooperation', relations would become active again. A good example is the collaboration with Rishon Le Zion (Israel), which is characterized by regular periods of inactivity in cooperation; and also collaboration with Alcala de Henares - a city in Spain. Relations with the Spanish city, after a short period of intensive cooperation, disappeared along with a change in the Spanish city's authorities. In recent times, regardless of the government offices, educational institutions from Lublin and Alcala de Henares have established cooperation. Moreover, interlocutors have admitted that the list of foreign partners is too broad and, in retrospect, Lublin should have chosen better partners - for example, Chinese cities.

\section{The financial factor}

In Lublin, international activities are financed by the city using its own funds on a decreasing scale. Cooperation is financed primarily from external resources. Without the external funding, Lublin would be able to carry out only $30 \%$ of activities that are being carried out now. When it comes to the principles of financing international cooperation in Nancy, it is financed using its own funds and funds coming from various foundations. Specific projects, mostly large, are financed with subsidies from the ministry and from EU funds.

In both French and Polish cities cross-border cooperation is financed from the same sources. What differentiates these two cities is the share of individual measures. In Lublin, officials pointed out that the share of external funds for the financing of international activities is growing from year to year.

\section{Conclusion}

In spite of the differences in local government systems and legal acts, it is possible to identify three main trends that occur in both cities. Firstly: the political factor, to the greatest extent, determines actions undertaken within the framework of crossborder cooperation. The executive authority is the key figure in influencing the cities' attitudes on the international scene. The next trend relates to the administration factor. It is the second factor in terms of importance influencing the attitudes of municipal governments in cross-border cooperation. The administration, in Lublin and Nancy, is responsible for carrying out tasks related to international cooperation. Both city halls are dealing with cooperation within the city office, as well as the flow of knowledge. As indicated in the theories on international cooperation (see Szromnik 2008; Baldersheim \& Stahlberg 1999), in order to develop collaboration, the efficient organizational structure of local administration and an internalization of knowledge about cooperation within the office, are required. The third trend refers to financial resources. Among the factors analysed in the study, financial issues have a minimal impact on the cities' position in cross-border cooperation. In general, financial subjects constitute an important determinant in the cooperation. However, this is not the most important factor for the attitudes of local governments on the international scene. The Polish local government example shows that international actions can be financed from external sources (see Satoła 2009a, 2009b; Szmigiel-Rawska \& Dołzbłasz 2012). 
Allies, P, Baraire, A \& Negrier, E 2003, L'action internationale des collectivites locales engagement citoyen et mondialisation, 3eme assises de la cooperation decentralisee, La documentation française, Paris.

Baldersheim, H \& Stahlberg, K 1999, Nordic region building in a European perspective, Ashgate Publishing Ltd, Hants, Vermont.

Brzozowska, A 1998, Związki bliźniacze. Współpraca międzynarodowa samorządów lokalnych, ZMP Poznań.

Cieśla, S 2000, 'Globalizacja i metropolizacja. Niektóre aspekty badań polskiej przestrzeni.', Studia Regionalne i Lokalne, no. 4(4)/2000, pp. 23-35.

Clarke, N 2010, 'Town twinning in Cold- War Britain: (Dis) continuities in twentieth-century municipal internationalism', Contemporary British History, vol. 24(2), pp. 173-191.

Fuksiewicz, A, Łada, A \& Wenerski, Ł 2012, Współpraca zagraniczna polskich samorządów, Instytut Spraw Publicznych, Warszawa.

Giddens, A 1990, The consequences of modernity, Polity Press, Cambridge.

Hałas, K \& Porawski, A 2003, Miasta i gminy bliźniacze, Urząd Komitetu Integracji Europejskiej.

Hermann, MG 1998, 'Elementy przywództwa' in Władza i społeczeństwo 2, eds J Szczupaczyński, Wydawnictwo Naukowe Scholar, Warszawa, pp. 297-313.

Kersting, N \& Vetter, A 2003, Reforming Local Government in Europe. Closing the Gap between Democracy and Efficiency, Leske+Budrich, Opladen.

Kocot, D 2006, 'Cechy i struktura organizacji "uczącej się"', e-Fakty 3/2006, Available from: <http://www.logistyka.net.pl/ images/articles/4565/e-F2006-3s10.pdf>. [10.05.2014].

Konstańczak, S 2001, Internalizacja wartości moralnych, Wydawnictwo Uczelniane PAP, Słupsk.

Mintron, M \& Norman, P 2009, 'Policy Entrepreneurship and Policy Change', The Policy Studies Journal, vol. 37, no. 4, 2009, pp. 649-667.
Satoła, Ł 2009a, 'Finansowe wspieranie budżetów gmin wybranymi funduszami strukturalnymi Unii Europejskiej', Rocznik Nauk Rolniczych, seria G, t. 96, z. 3, pp. 58-66.

Satoła, Ł 2009b, 'Znaczenie funduszy UE we wspieraniu rozwoju lokalnego', Oeconomia, vol. 8 (1) 2009, pp. 199-210.

Stoner, JAF, Freeman, RE \& Gilbert, JR DR 2001, Kierowanie, PWE, Warszawa.

Szewczyk, J 2007, 'Zagraniczne związki partnerskie polskich samorządów miast, powiatów i województw', Prace geograficzne, vol. 117, Kraków, pp. 259-273.

Szmigiel-Rawska, K 2008, 'Relacje, konkurencja, współpraca. Próby znalezienia właściwych definicji dla działań podejmowanych na arenie międzynarodowej przez regiony administracyjne.' in Przekształcenia regionalnych struktur funkcjonalno-przestrzennych. Europa bez granic, Instytut Geografii i Rozwoju Regionalnego Uniwersytetu Wrocławskiego, Wrocław, pp. 47-55.

Szmigiel-Rawska, K \& Dołzbłasz, S 2012, Trwałość współpracy przygranicznej, CeDeWu, Warszawa.

Szmigiel-Rawska, K, Dziemianowicz, W \& Szlachta, J 2010, Samorząd lokalny w sieciach gospodarczych, Uniwersytet Warszawski, Wydział Geografii i Studiów Regionalnych, Warszawa.

Szromnik, A 2008, Marketing terytorialny, Wolters Kluwer, Warszawa.

Tucker, RC 1981, Politics as Leadership, University of Missouri Press, Columbia.

Wollmann, H \& Bouckaert, G 2006, 'State Organization in France and Germany between territoriality and functionality' in State and Local Governments Reforms in France and Germany. Divergence and Convergence, eds V Hoffmann-Martinot \& $H$ Wollmann, $H$, Vs. Verlag fur Sozialwissenschaften, pp. 11-37. 